\title{
Pengembangan Model Pembelajaran Blended Learning pada Pendidikan Kesetaraan Program Paket C dalam Meningkatkan Kemandirian Belajar
}

\begin{abstract}
Anan Sutisna*
Abstract: This research aimed at discovering a instructional model to improve self learning of students package C program. Alternative selected to reach the objective of this research to develop a instructional model of Blended Learning, focusing at self learning. The instructional model was developed based on the fact and consideration that the on going instruction process was regarded too conventional. Learning Blended learning model on the package C program is conducted by the method of research and development through three stages: a preliminary study, the preparation of conceptual models and test to determine the effectiveness of the model. The result showed that instructional model of Blended Learning is effective to improve the self learning of students package C program at the Center for Community Learning.
\end{abstract}

Key words: Instructional Model of Blended Learning, and Self Learning

\begin{abstract}
Abstrak: Penelitian ini bertujuan untuk menemukan suatu model pembelajaran yang dapat meningkatkan kemandirian belajar peserta didik program paket $C$. Alternatif yang ditempuh untuk mencapai tujuan tersebut dengan mengembangkan model pembelajaran Blended Learning yang menitikberatkan pada kemandirian belajar. Pengembangan model pembelajaran ini dilandasi oleh fakta dan pemikiran bahwa proses pembelajaran yang selama ini dilaksanakan cenderung bersifat konvensional. Model pembelajaran Blended Learning pada program paket $C$ ini dilakukan dengan metode penelitian dan pengembangan melalui tiga tahapan yaitu studi pendahuluan, penyusunan konseptual model dan ujicoba untuk menentukan efektivitas model. Hasil penelitian menunjukkan bahwa model pembelajaran Blended Learning efektif untuk meningkatkan kemandirian belajar peserta didik program paket $C$ di Pusat Kegiatan Belajar Masyarakat.
\end{abstract}

Kata Kunci : Model Pembelajaran Blended Learning dan Kemandirian Belajar

\section{PENDAHULUAN}

Pendidikan kesetaraan adalah pendidikan yang berlangsung di luar sistem persekolahan, namun kompetensi lulusannya dianggap setara dengan kompetensi lulusan pendidikan formal setelah dilakukan pengujian oleh lembaga yang memiliki kewenangan yang ditunjuk oleh pemerintah sesuai perintah Undang-undang. Walaupun demikian pendidikan kesetaraan seakan termarginalkan dari perhatian publik karena wujud penyelenggaraannya di dalam masyarakat tidak begitu popular. Padahal pendidikan kesetaraan memberikan andil yang cukup signifikan dalam menyumbangkan angka partisipasi kasar (APK) dan angka partisipasi murni (APM) pendidikan, baik Paket A setara SD/MI, Paket B setara SMP/MTs, dan Paket C setara SMA/MA ( Suryadi, 2006:23)

Dalam situasi masyarakat yang selalu berubah, idealnya pendidikan kesetaraan tidak hanya berorientasi pada masa lalu dan masa kini, yang senantiasa dilaksanakan dengan mengacu pada pendidikan formal, yakni berkelompok,

\footnotetext{
* Dosen Program Studi Pendidikan Luar Sekolah Fakultas Ilmu Pendidikan Universitas Negeri Jakarta. Jl. Rawamangun Muka Komplek Kampus UNJ, Jakarta 13220,Telp.021-4897535, Email: ananplsunj@yahoo.com
} 
mempergunakan narasumber dari kalangan guru formal, serta metode pembelajarannya sentaralistik (teaching center), sebab diketahui bersama bahwa karakeristik sasaran pendidikan kesetaraan sangat beragam ditinjau dari tingkat umur, ekonomi, letak geografis dan keadaan sosial budaya. Peserta didik pendidikan kesetaraan adalah orang-orang yang memiliki pemikiran kritis rasional, artinya apa yang dia lakukan berorientasi pada keuntungan dirinya pada saat itu, tanpa memikirkan bagaimana pentingnya pendidikan dalam kehidupan.

Paradigma pendidikan kesetaraan yang menganggap sasarannya adalah orang-orang kurang beruntung dan termarginalkan, perlu mengalami revolusi dan pencerahan. Bahwa sasaran pendidikan kesetaraan dewasa ini bukan hanya orang yang kurang beruntung dan termarginalkan, tetapi juga melayani orang-orang yang memilih pendidikan kesetaraan, sebagai suatu pilihan artinya bahwa sasaran pendidikan keseteraan adalah orang-orang yang mampu baik secara intelektual maupun secara material, hanya karena persoalan kesempatan dan waktu yang dimiliki sangat terbatas. Oleh karena itu pemahaman tentang pembelajaran pada pendidikan kesetaraan yang pada dasarnya tidak hanya mempelajari tentang konsep, teori dan fakta, tetapi lebih mementingkan aplikasi dalam kehidupan sehari-hari, menuntut bagi para penyelenggara pendidikan untuk lebih bijaksana memilih tutor yang memiliki pengetahuan dan pengalaman tentang model-model dan strategi pembelajaran yang berbasis pada Teknologi Informasi dan Komunikasi (TIK), misalnya pembelajaran program paket $\mathrm{C}$ melalui internet.

Sebagai bahan perbandingan tentang penggunaan pembelajaran yang mengunakan TIK sebagaimana hasil penelitian yang dilakukan oleh Didarul Islam Manik and Charles A. Lubbers, (2016 : 267) tentang penggunaan sumber daya online informasi oleh petani di Bangladesh. Penelitian ini bertujuan mengeksplorasi akses dan penggunaan informasi oleh petani, dengan mengambil "difusi inovasi" model Roger sebagai kerangka teoritis. Metode pengumpulan data dalam penelitian menggunakan kuantitatif dan kualitatif. Untuk data kuantitatif, kuesioner digunakan untuk mengumpulkan informasi dari responden. Sedangkan data kualitatif, dilakukan dengan wawancara di kalangan petani. Beberapa penyuluh pertanian (penyelia layanan) juga diwawancarai untuk menilai pola layanan mereka kepada petani. Hasil penelirtian ini menunjukan bahwa sebagian besar petani tidak akrab dengan sumber informasi pertanian secara online karena kurangnya fasilitas teknologi, seperti komputer dan koneksi internet. Petani tidak khawatir tentang menggunakan TIK atau sumber informasi online. Tetapi mereka khawatir tentang harga rendah produk mereka dan harga tinggi dari benih, pupuk, pestisida, bahan bakar serta transportasi. Sumber informasi utama yang petani peroleh dari media televisi, radio, koran, sesama petani dan penyelia layanan penyuluhan pertanian.

Untuk mendukung terjadinya kemandirian belajar peserta didik, maka peran tutor sebagai fasilitator atau pendamping peserta didik, yang didalamnya berperan sebagai catalicator, process helper, resources linker, and solution giver. (Havelock, 1991: 211). Kemandirian belajar memiliki tujuan (a) membebaskan peserta didik dari pola pembelajaran yang konvensional, (b) membuka kesempatan belajar sesuai kemampuan, dan (c) 
membangun suatu pola pembelajaran yang membimbing peserta didik menuju self directed learning (Wedemeyer, 1979 : 17 ).

Disamping itu juga diperlukan aspek kehadiran sosial dalam pembelajaran sebagaimana hasil penelitian Rosemarie Garner and Elizabeth Rouse (2016 : 25) bahwa di Australia agenda reformasi nasional untuk pendidikan anak usia dini dan perawatan telah menyebabkan peningkatan permintaan untuk guru anak usia dini yang berkualitas. Sebagai tanggapan, universitas telah mengembangkan pendekatan inovatif dalam memberikan program pendidikan guru anak usia dini yang dirancang untuk mendukung diploma pendidik yang berkualitas yang ada untuk mendapatkan kualifikasi mengajar mereka. Dengan studi yang dilakukan berbasis masyarakat, on line e-learning dan tatap muka tutorial intensif. Penelitian ini menyimpulkan bahwa dimasukkannya kontak dan kehadiran sosial dalam lingkungan pembelajaran online sangat berpengaruh.

Semangat untuk mengkaji dan mengembangkan suatu model dan strategi pembelajaran yang memadukan antara pembelajaran konvensional dengan menggunakan Teknologi Informasi dan Komunikasi untuk meningkatkan kemandirian belajar. Maka salah satu model pembelajaran Blended Learning yaitu pembelajaran tatap muka yang menggunakan CD interaktif dan ebook dalam jaringan internet. Sebagaimana hasil penelitian Gillian Lord \& Lara Lomicka (2008 : 158) bahwa pengembangan komunitas online tidak hanya dalam pendidikan jarak jauh tetapi juga dalam program hybrid yang menggabungkan fitur dari pendidikan jarak jauh online dengan pembelajaran berbasis kelas tradisional. Hybrid jenis program ini sering disebut sebagai pembelajaran blended, menggabungkan beberapa jenis pedagogi dengan alat yang berbeda untuk interaksi dan diskusi. Blended learning sebagai campuran kelas tradisional dan pembelajaran online yang mencakup beberapa kenyamanan dan tanpa menghilangkan makna kontak face to face.

Blended Learning merupakan metode belajar yang menggabungkan dua atau lebih metode dan pendekatan dalam pembelajaran untuk mencapai tujuan proses pembelajaran. Menurut Thorne (2003 : 16) bahwa apa yang terjadi dalam kelas konvensional dimana pendidik dan peserta didik bertemu langsung, dengan pembelajaran online yang bisa diakses kapan dan dimana saja. Adapun bentuk lain dari blended learning adalah pertemuan virtual antara pendidik dan peserta didik. Dimana mereka memungkinkan berada di dunia yang berbeda, namun bisa saling memberi feedback, bertanya, menjawab, berinteraksi antara peserta didik dengan pendidik atau antara peserta didik dengan peserta didik.

Menurut Bersin, (2004 : 15) Blended learning is the combination of diffrent training media (technologies, activities, and types of events) to create an optimum training program for a specific audience. The term (blended) mean that tradisional instructur-led training is being supplemented with olther electronic formats. In the contex of the book blended learning program use many different forms of e-learning, perhaps complement with instructorled training in orther live formats.

Berdasarkan pendapat Bersin di atas, maka dapat disimpulkan bahwa blended learning adalah kombinasi dari berbagai media teknologi, kegiatan dan jenis peristiwa untuk menciptakan program 
pelatihan yang optimal bag peserta secara spesifik. Program pembelajaran ini menggunakan berbagai bentuk e-learning baik dengan instruktur pelatihan maupun format langsung. Dengan demikian blended learning merupakan suatu model pembelajaran yang memadukan kekuatan pembelajaran tradisional tatap muka dengan lingkungan pembelajaran elektronik.

Sejalan dengan pembelajaran blended learning terdapat hasil penelitian Ibrahim Aly (2016 : 325) yang relevan yaitu penelitian yang mengambil tampilan empiris pada tiga area perbandingan belajar yang berbeda lingkungan yaitu (1) tatap muka, (2) on-line dan (3) campuran (blended learning) pada materi Pengantar Akuntansi Manajerial. Dimana penelitian ini membandingkan hasil ujian tengah semester, ujian akhir dan jumlah hasil nilai akhir siswa dalam kursus tersebut yang diajarkan oleh instruktur yang sama dengan menggunakan blended learning, tatap muka, dan penggunaan media online. Dalam analisis uji variance yang digunakan untuk menentukan apakah terdapat perbedaan yang signifikan terhadap hasil kinerja siswa dalam kursus tersebut. Hasil penelitian ini menunjukkan bahwa tidak ada perbedaan yang signifikan dalam tiga lingkungan belajar yang berbeda. Dengan demikian penelitian ini menyimpulkan bahwa instruktur dan pedagogi lebih penting untuk belajar siswa dari pada jenis media pengiriman dan instruktur harus memfokuskan pada kualitas merancang dan mengembangkan konten.

Hal ini diperkuat oleh hasil penelitian Won Sun Chen and Adrian Yong Tat Yao (2016 : 1667) bahwa tingkat kepuasan peserta didik dengan blended learning memainkan peran penting. Oleh karena itu fokus penelitiannya pada faktor-faktor utama yang mempengaruhi kepuasan peserta didik di lingkungan blended learning. Ada enam dimensi yaitu (1) pelajar, (2) instruktur, (3) lembaga, (4) teknologi, (5) desain dan (6) lingkungan, yang menjadi indikator kepuasan peserta didik khususnya pada komponen e-learning dalam lingkungan blended learning. Dimana dalam penelitian tersebut disimpulkan bahwa peserta didik (generasi muda) diprioritaskan dimensi desain menjadi faktor yang paling penting dalam kepuasan mereka terhadap $e$ learning komponen dalam lingkungan blended learning. Oleh karena itu, mungkin lebih strategis bagi lembaga pendidikan untuk menekankan pada dimensi desain dalam implementasi e-learning mereka dalam lingkungan blended learning khusus untuk peserta didik yang lebih muda.

Berdasarkan pengertian dan keunggulan blended learning di atas, maka hasil penelitian Yamanto Isa (2015: 83) menunjukkan bahwa pengembangan model blended learning mampu meningkatkan hasil belajar mahasiswa dan lebih mudah memahami materi baik melalui pembelajaran tradisional maupun menggunakan e-learning. Atas dasar hasil penelitian tersebut, maka rumusan masalah dalam penelitian ini adalah sebagai berikut: (1) Bagaimana model konseptual pembelajaran blended learning untuk meningkatkan kemaandirian belajar peserta didik pada program paket C? (2) Bagaimana penerapan model pembelajaran blended learning untuk meningkatkan kemandirian belajar peserta didik pada program paket C? dan (3) Apakah efektif model pembelajaran blended learning untuk meningkatkan kemandirian belajar peserta didik pada program paket C di Pusat Kegiatan Belajar Masyarakat? 


\section{METODE PENELITIAN}

Untuk mencapai tujuan penelitian ini ditempuh pendekatan penelitian dan pengembangan pendidikan (educational research and development) sebagaimana yang ditulis oleh Borg dan Gall (2003 : 570). Educational research and development $(R \&$ $D)$ adalah proses untuk mengembangkan dan memvalidasi produk pendidikan yang berupa tujuan belajar, metode, kurikulum, evaluasi, baik perangkat keras, lunak maupun cara atau prosedurnya. Tujuan akhir dari R \& D pendidikan adalah lahirnya produk baru untuk meningkatkan performa kerja pendidikan dan pembelajaran. Dengan demikian proses pembelajaran menjadi lebih efektif dan/atau lebih efisien, serta sesuai dengan tuntutan kebutuhan.

Dalam penelitian dan pengembangan utamanya menggunakan tiga metode, yaitu survey, evaluatif, dan eksperimen (Sugiyono, 2007: 316). Survey digunakan dalam penelitian pendahuluan untuk mengetahui kondisi pendukung dan praktek yang terkait dengan produk yang akan dikembangkan. Sedangkan penggunaan metode eksperimen dalam penelitian ini merujuk pada desain Pre- eksperimen. Dimana metode penelitian pre-eksperimen, peneliti menggunakan pendekatan One Group Pretest-Posttest Design. Hasil yang diukur adalah kemandirian belajar peserta didik dengan menilai hasil belajar yang diberikan tes sebelum (pretest) dan tes setelah penggunaan media CD interaktif dan e-book (posttest), dengan menggunakan materi yang sama. Hasil test awal (pretest) akan dibandingkan dengan test akhir (posttest) setelah mendapatkan perlakuan. Desain eksperimen terdiri atas satu kelas kelompok eksperimen. Pemilihan kelas eksperimen berdasarkan atas tujuan dan karakteristik yang telah ditentukan sebelumnya, (Sukardi, 2003 : 75).

Prosedur yang ditempuh secara operasinal dalam penelitian dan pengembangan ini melalui tiga tahapan yaitu: (1) studi pendahuluan, penyusunan model konseptual dan (3) uji efektivitas model pembelajaran.

Studi pendahuluan dilakukan untuk mengetahui dan mendalami model-model pembelajaran yang ada sekarang di beberapa lembaga penyelenggara pendidikan kesetaraan di propinsi DKI Jakarta seperti Pusat Kegiatan Belajar Masyarakat (PKBM). Persoalan yang dieksplorasi dalam studi pendahulaun tersebut meliputi (1) model - model pembelajaran program paket $\mathrm{C}$ yang yang dilakukan sekarang. (2) metode dan strategi pembelajaran yang dilakukan penyelenggara maupun tutor, (3) aktivitas peserta didik dalam mengikuti kegiatan pembelajaran, (4) peranan tutor dalam pengelolaan dan pengendalian pembelajaran, (5) kegiatan belajar yang diinginkan oleh peserta didik, (6) kegiatan penilaian dalam pembelajaran, (7) tindak lanjut pembelajaran.

Pengembangan model konseptual dilakukan dengan prosedur (1) penentuan komponen model berdasarkan informasi teoretik, dan (2) validasi ahli dan praktisi. Penentuan komponen model dilakukan dengan cara mengkaji secara kritis hasil-hasil studi pendahuluan dan ekplorasi lapangan terdahulu, menarik preskripsi dari kajian literatur tentang model pembelajaran, khususnya teori dan praktik pembelajaran di lembaga penyelenggara program paket C. Pengembangan perangkat dan substansi model dilakukan dengan prosedur (1) identifikasi perangkat dan isi model, (2) pengembangan perangkat dan substansi model, dan (3) validasi ahli 
dan uji-coba perangkat model. Identifikasi perangkat dan substansi model dilakukan dengan cara menganalisis karakteristik pembelajaran blended learning, dan secara simultan dikaitkan dengan peningkatan kemandirian belajar yang telah disiapkan sebelumnya. Uji-coba perangkat model dilakukan dengan metode limited field-trial dengan bekerjasama dengan beberapa lembaga yang mengelola pembelajaran paket $\mathrm{C}$ yang ada di provinsi DKI Jakarta.

Uji coba model yang lebih luas untuk mengetahui efektifitas model melalui tindakan berulang dilakukan dengan berdasar pada pendapat Hopkins (1993 : 121) yang meliputi kegiatan (1) perencanaan strategi implementasi pembelajaran, (2) pelaksanaan pembelajaran, (3) refleksi hasil dan proses pembelajaran, dan (4) observasi serta perbaikan proses pembelajaran. Dalam siklus pembelajaran ini diperlukan dua kali siklus pelaksanaan pembelajaran dengan peserta didik yang berbeda dan lembaga pembelajaran yang berbeda pula. Pertama dilakukan di laboratorium pelatihan Jurusan PLS yang ada dalam Kampus UNJ, Kedua dilakukan di Pusat Kegiatan Belajar Masyarakat. Sehingga dimungkinkan adanya variasi dan akurasi data yang lebih lengkap untuk memperbaiki model pembelajaran yang dianggap efektif dalam peningkatan kemandirian belajar yang diharapkan.

Analisis data dalam penelitian ini dilakukan secara kualitatif dan kuantitatif, terhadap implementasi model pembelajaran. Analisis kualitatif digunakan untuk mendeskripsikan hasil penelitian pendahuluan, analisis kuantitatif terkait dengan keterlaksanaan dan pengaruh model yang dikembangkan. Analisis kuantitatif digunakan analisis statistic (Iskandar, 2009 : 17). Kegiatan dalam analisis data meliputi mengelompokkan data berdasarkan variabel dan jenis responden, mentabulasi data berdasarkan variabel dari seluruh responden, menyajikan data tiap variabel yang diteliti, melakukan perhitungan untuk menjawab rumusan masalah, dan melakukan perhitungan untuk menguji hipotesis yang telah diajukan.

Adapun analisis data yang dimaksud ialah dengan menguji hipotesis penelitian dengan menggunakan pengujian kesamaan dua rata-rata: uji dua pihak, yaitu dengan uji t. Data didapat dari data pretest dan posttest melalui angket. Rumus $\mathrm{t}$ tersebut dibandingkan dengan $t_{1}-\alpha$, dimana $t_{1}-\alpha$ didapat dari daftar distribusi $\mathrm{t}$ dengan peluang $(1-\alpha)$ dan $\mathrm{dk}$ $=\left(\mathrm{n}_{1}+\mathrm{n}_{2}-2\right)$. Untuk menguji hipotesis, yaitu melihat ada atau tidaknya perbedaan hasil hitung observasi kemandirian belajar sebelum eksperimen dengan hasil hitung observasi kemandirian setelah eksperimen digunakan uji t dengan taraf signifikan $\alpha=0,05$.

\section{HASIL PENELITIAN}

Berdasarkan hasil analisis data dan sesuai dengan langkah-langkah penelitian dan pengembangan, maka hasil penelitian menunjukan bahwa: Pertama aspek perencanaan pembelajaran yang meliputi: (1) Mengidentifikasi topik mata pelajaran yang akan diberikan $60 \%$, (2) Melakukan pembuatan rencana persiapan sebelum pembelajaran $70 \%$, (3) Menentukan strategi pembelajaran sesuai karakteristik peserta didik 50\%, (4) Ketepatan pemilihan materi pembelajaran $60 \%$, Sistematika penyusunan materi pembelajaran $40 \%$, (6) Ketepatan rumusan tujuan yang akan dicapai $50 \%$ dan (7) Kesesuaian media pembelajaran dengan karakteristik peserta didik $10 \%$. 
Kedua aspek pengorganisasian pembelajaran terdiri dari (1) Pengorganisasian warga belajar dalam penggunaan media pembelajaran $60 \%$ dan (2) Pengaturan kegiatan pembelajaran dengan menggunakan CD interaktif dan e-book $20 \%$.

Ketiga aspek pelaksanaan proses pembelajaran terdiri dari (1) Penyampaian tujuan yang akan dicapai ketika membuka pelajaran 50\%, (2) Penyajian materi secara sistematis dalam pembelajaran 60\%, (3) Kesesuaian media pembelajaran dengan karakteristik peserta didik $40 \%$, (4) Ketetapan penggunaan media dalam pembelajaran 20\%, (5) Kesesuaian media dengan kebutuhan peserta didik 40\%, (6) Penggunaan media sesuai dengan tujuan pembelajaran $10 \%$, (7) Penggunakan metode sesuai dengan media pembelajaran yang digunakan $40 \%$, (8) Penggunaan media sesuai dengan karakteristik peserta didik $50 \%$, (9) Pengunaan waktu secara proporsional untuk pembukaan, inti dan penutup 30\%, (10) Kesesuaian materi pelajaran dengan pengalaman yang dimiliki warga belajar 50\%, (11) Peserta didik terlibat secara aktif dalam pembelajaran $30 \%$, (12) Adanya penguatan secara bervariasi dengan waktu yang tepat dan konsisten $30 \%$, (13) Pemberian kesimpulan pada akhir pembelajaran $60 \%$, (14) Penggunaan bahasa dalam media pembelajaran mudah dipahami 40\%, (15) Media mengandung substansi materi mata pelajaran yang akan diajarkan $20 \%$ dan (16) Suasana pembelajaran dengan menggunakan media sangat dinamis $60 \%$

Keempat aspek penilaian pembelajaran terdiri dari (1) Media pembelajaran membantu memperjelas materi belajar 10\%, (2) Ketepatan prosedur dan jenis penilaian hasil belajar 60\%, (3) Kesesuaian alat penilaian dengan materi yang disampaikan 70\%, (4) Penulisan butir soal dijabarkan dalam kisi-kisi dan menggunakan bahasa yang mudah dipahami 50\% dan (5) Melaksanakan penilaian hasil belajar dalam proses pembelajaran $50 \%$.

\section{Konseptual Model Pembelajaran}

Prosedur yang ditempuh dalam mengimplementasikan model pembelajaran blended learning ini, melalui tiga tahapan, yakni: (1) perencanaan, (2) pelaksanaan, dan (3) evaluasi. Masing-masing tahapan tersebut dapat di jelaskan sebagai berikut:

1) Tahap Perencanaan dalam implementasi model ini menempuh beberapa kegiatan antara lain: (1) Identifikasi kebutuhan belajar, dimana tutor dan peserta didik menentukan materi apa yang akan disampaikan dalam pembelajaran sesuai dengan kurikulum program paket C setara SMA. (2) Menetapkan jenis media pembelajaran yang berbasis TIK yaitu e-book dan CD interaktif. Dimana media e-book berisikan materi tentang Pelajaran Sosiologi dengan pokok bahasan konfik sosial, sedangkan media CD interaktif berisikan materi tentang pelajaran bahasa inggris dengan topik tentang Preposition.

2) Tahap Pelaksanaan pembelajaran blended learning tutor berperan sebagai fasilitator dan bertindak sebagai sumber belajar untuk memfasilitasi terjadinya kegiatan proses pembelajaran dengan langkah-langkah: menyampaikan tujuan (kompetensi) yang akan dicapai, (2) mendeskripsikan materi secara singkat; (3) menjelaskan langkah-langkah penggunaan media e-book dan CD interaktif, sehingga memberikan pengalaman belajar 
kepada peserta didik, dengan penggunaan media memfasilitasi warga belajar untuk melakukan pembelajaran mandiri; dan (4) melakukan pembelajaran mandiri dengan menggunakan media e-book dan CD interaktif dalam implementasi pembelajaran paket $\mathrm{C}$.

Peserta didik program paket $\mathrm{C}$ bertindak secara individual maupun kelompok melalukan kolaboratif dengan tutor dalam melaksanakan kegiatan pembelajaran dengan langkah-langkah: (1) menyimak uraian materi secara seksama; (2) melakukan kegiatan pembelajaran dengan menggunakan media e-book dan CD interaktif sesuai materi yang diajarkan oleh tutor; (3) melakukan pembelajaran mandiri dengan menggunakan media e-book dan CD interaktif dalam kegiatan pembelajaran ini melalui langkah-langkah: (a) menghidupkan komputer, (b) melaksanakan pembelajaran mandiri, (c) mengoperasikan komputer untuk menggunakan media e-book dan CD interakasi, dan (d) merencanakan pembelajaran mandiri tahap selanjutnya. Langkah-langkah tersebut ditempuh bertujuan untuk lebih meningkatkan kemandirian belajar peserta didik dalam pembelajaran secara aktual.

3) Tahap evaluasi dilakukan berdasarkan kriteria dan instrumen yang akan digunakan untuk menilai efektivitas model pembelajaran. Evaluasi efektivitas model ditempuh melalui tiga tahap penilaian, yaitu (1) penilaian terhadap hasil pembelajaran (outpu)t; (2) evaluasi terhadap proses implementasi model, dan (3) evaluasi terhadap dampak implementasi model (outcome). Evaluasi hasil pembelajaran dilakukan untuk mengukur tingkat efektivitas keberhasilan pembelajaran melalui pengujian awal (pre test) untuk mengetahui tingkat penguasaan materi belajar, dilakukan sebelum implementasi ujicoba model, dan pengujian akhir (post test) dilakukan pada akhir keseluruhan proses pembelajaran setelah berakhir, melalui test. Evaluasi proses pembelajaran dilakukan untuk mengukur efektivitas penerapan model pembelajaran, melalui penyebaran angket tentang pendapat peserta didik dalam model pembelajaraan yang dikembangkan. Evaluasi dampak implementasi model (outcome), dilakukan pada kegiatan reflektif untuk mengetahui kemandirian belajar, dilaksanakan melalui penyebaran angket terhadap peserta didik di kelompok belajar paket $\mathrm{C}$.

\section{Implementasi Model Pembelajaran}

Implementasi model pembelajaran ini untuk membuktikan seberapa besar model pembelajaran blended learning memberikan pengaruh terhadap peningkatan kemandirian belajar peserta didik program paket $\mathrm{C}$, setelah itu dilakukan uji t dua belahan (two tails), dengan signifikansi $\alpha=0,05$.

Pengujian hipotesis penelitian yang dilakukan dalam penelitian ini, yakni: Ho: Tidak terdapat pengaruh penggunaan media pembelajaran CD interaktif dan e-book terhadap peningkatan kemandirian belajar peserta didik program paket $\mathrm{C}$ pada PKBM di DKI Jakarta. $\mathrm{H}_{1}$ : Terdapat pengaruh dalam penggunaan media pembelajaran $\mathrm{CD}$ interaktif dan e-book terhadap peningkatan kemandirian belajar peserta didik program paket $\mathrm{C}$ pada PKBM di DKI Jakarta. Berdasarkan pengajuan hipotesis tersebut, diperoleh data hasil penelitian yang menunjukkan bahwa skor rerata posttest lebih besar dari skor rerata pretest $\left(\mathrm{x}_{1}>\mathrm{x}_{2}\right)$. Adapun 
perhitungan pengujian hipotesis tersebut dapat dilihat pada tabel di bawah ini:

Tabel 1

Perhitungan Statistik Skor Pretest dan Skor Posttest

\begin{tabular}{|c|c|c|c|c|c|c|c|c|}
\hline \multirow{2}{*}{$\begin{array}{l}\text { No. } \\
\text { Res. }\end{array}$} & \multicolumn{2}{|c|}{ Pretest } & \multirow{2}{*}{$\left(\mathrm{x}_{2}-\square \mathrm{x}_{2}\right)$} & \multirow{2}{*}{$\left(\mathrm{x}_{2}-\square \mathrm{x}_{2}\right)^{2}$} & \multicolumn{2}{|c|}{ Posttest } & \multirow{2}{*}{$\left(\mathrm{x}_{1}-\square \mathrm{x}_{1}\right)$} & \multirow{2}{*}{$\left(\mathrm{x}_{1}-\square \mathrm{x}_{1}\right)^{2}$} \\
\hline & $\left(\mathrm{x}_{2}\right)$ & Nilai & & & $\left(\mathrm{x}_{1}\right)$ & Nilai & & \\
\hline 1 & 17 & 57 & 1.21 & 1.47 & 21 & 70 & 1.50 & 2.25 \\
\hline 2 & 17 & 57 & 1.21 & 1.47 & 29 & 97 & 2.07 & 4.29 \\
\hline 3 & 17 & 57 & 1.21 & 1.47 & 20 & 67 & 1.43 & 2.04 \\
\hline 4 & 14 & 47 & 1.00 & 1.00 & 21 & 70 & 1.50 & 2.25 \\
\hline 5 & 22 & 73 & 1.57 & 2.47 & 25 & 83 & 1.79 & 3.19 \\
\hline 6 & 19 & 63 & 1.36 & 1.84 & 24 & 80 & 1.71 & 2.94 \\
\hline 7 & 19 & 63 & 1.36 & 1.84 & 29 & 97 & 2.07 & 4.29 \\
\hline 8 & 11 & 37 & 0.79 & 0.62 & 25 & 83 & 1.79 & 3.19 \\
\hline 9 & 12 & 40 & 0.86 & 0.73 & 19 & 63 & 1.36 & 1.84 \\
\hline 10 & 11 & 37 & 0.79 & 0.62 & 21 & 70 & 1.50 & 2.25 \\
\hline 11 & 18 & 60 & 1.29 & 1.65 & 27 & 90 & 1.93 & 3.72 \\
\hline 12 & 18 & 60 & 1.29 & 1.65 & 25 & 83 & 1.79 & 3.19 \\
\hline 13 & 12 & 40 & 0.86 & 0.73 & 19 & 63 & 1.36 & 1.84 \\
\hline 14 & 11 & 37 & 0.79 & 0.62 & 19 & 63 & 1.36 & 1.84 \\
\hline$\Sigma$ & 218 & 728 & & 18.20 & 324 & 1079 & & 39.12 \\
\hline$-\square \mathbf{x}$ & 15.6 & & & & 23.14 & & & \\
\hline $\mathrm{s}^{2}$ & 1.40 & & & & 3.01 & & & \\
\hline$S$ & 1.18 & & & & 1.73 & & & \\
\hline
\end{tabular}

Berdasarkan perhitungan diperoleh $\mathrm{t}_{\text {hitung }}=$ Dengan demikian Ho ditolak dan $\mathrm{H}_{1}$ diterima yang 3,57, maka mencari $t_{\text {tabel }}$ dengan derajat kebebasan berarti terdapat pengaruh penggunaan media $(\mathrm{dk})=\mathrm{n}_{1}+\mathrm{n}_{2}-2$, yaitu $=14+14-2=26$. Jadi pembelajaran CD interaktif dan e-book terhadap diperoleh $\mathrm{t}_{\text {tabel }}=1.706$. Sehingga kesimpulan $\mathrm{t}_{\text {hitung }}=$ peningkatan kemandirian belajar peserta didik $3.57>t_{\text {tabel }}=1,706$ dengan taraf signifikan 0.05. program paket $\mathrm{C}$ pada PKBM di DKI Jakarta.

Tabel 2

Perhitungan Selisih Nilai Pretest dan Nilai Posttest

\begin{tabular}{|c|c|c|c|c|}
\hline No. Resp & Nilai Pretest & Nilai Posttest & Selisih Nilai & Persentase (\%) \\
\hline 1 & 57 & 70 & 13 & 22.8 \\
\hline 2 & 57 & 97 & 40 & 70.2 \\
\hline 3 & 57 & 67 & 10 & 17.5 \\
\hline 4 & 47 & 70 & 23 & 48.9 \\
\hline 5 & 73 & 83 & 10 & 13.7 \\
\hline 6 & 63 & 80 & 17 & 27.0 \\
\hline 7 & 63 & 97 & 34 & 54.0 \\
\hline 8 & 37 & 83 & 46 & 124.3 \\
\hline 9 & 40 & 63 & 23 & 57.5 \\
\hline 10 & 37 & 70 & 33 & 89.2 \\
\hline 11 & 60 & 90 & 30 & 50.0 \\
\hline 12 & 60 & 83 & 23 & 38.3 \\
\hline 13 & 40 & 63 & 23 & 57.5 \\
\hline 14 & 37 & 63 & 26 & 70.3 \\
\hline Jumlah & $\mathbf{7 2 8}$ & $\mathbf{1 0 7 9}$ & $\mathbf{3 5 1}$ & - \\
\hline Rerata & $\mathbf{5 2}$ & $\mathbf{7 7}$ & $\mathbf{2 5}$ & $\mathbf{4 8 . 2}$ \\
\hline
\end{tabular}


Berdasarkan tabel di atas, bahwa nilai rerata pretest dari 14 orang peserta didik kelompok eksperimen ialah 52 dimana nilai tertinggi 73 dan nilai terendah 37. Hal ini menunjukkan bahwa tingkat kemandirian tergolong Kurang. Sedangkan nilai rerata yang diperoleh kelompok eksperimen ialah 77 dimana nilai tertinggi 97 serta nilai terendah 63. Secara keseluruhan, kemandirian belajar setelah diberikan perlakuan (treatment) diklasifikasikan ke dalam kategori Baik. Dengan demikian terjadi peningkatan rerata nilai pretest dan posttest peserta didik yakni dari 52 menjadi 77. Jadi kenaikan rerata nilai sebesar 25 poin atau $48,2 \%$ tersebut dapat dikategorikan dalam kategori penilaian Cukup Baik.

Maka dengan memperhatikan hasil pengujian hipotesis dan hasil selisih nilai pretes dan postes dapat disimpulkan bahwa efektif model pembelajaran blended learning dalam meningkatkan kemandirian belajar peserta didik program paket $\mathrm{C}$ pada Pusat Kegiatan Belajar Masyarakat di DKI Jakarta.

\section{PEMBAHASAN}

Penelitian

$$
\text { pengembangan }
$$

model

pembelajaran dalam penerapannya, telah memperoleh temuan yang menunjukkan efektivitas bagi terpenuhinya kebutuhan belajar peserta didik kesetaraan paket $\mathrm{C}$ dalam meningkatkan kemandirian belajarnya. Oleh sebab itu, keberartian hasil studi pengembangan model pembelajaran ini memiliki implikasi baik secara teoretis dalam menambah khasanah pengetahuan, maupun secara praktis untuk kebijakan operasional yang dapat diterapkan dalam pelaksanaan pembelajaran program paket $\mathrm{C}$ di $\mathrm{PKBM}$.
Dalam pengembangan pendidikan luar sekolah, model pembelajaran ini berkontribusi memperkuat teori-teori pembelajaran yang dapat menambah khasanah pengetahuan dalam dimensi pembelajaran pendidikan kesetaraan. Pembelajaran sebagai proses peningkatan sumber daya manusia sangat penting (human capital), artinya bahwa program-program pembelajaran dirancang dan dilaksanakan, pada dasarnya bertujuan untuk mengembangkan kemampuan individu atau kelampok, agar dapat meningkatkan intelektualnya (Kamil, 2007: 74).

\section{Model pembelajaran blended learning} dengan pengembangan media $\mathrm{CD}$ interaktif dan ebook dijadikan strategi dalam pembelajarannya, secara nyata telah dapat meningkatkan kemandirian belajar peserta didik dalam pendidikan kesetaraan paket C pada PKBM. Sesuai temuan empirik penerapan model ini menunjukkan efektivitasnya bagi terpenuhinya kebutuhan belajar peserta didik dalam upaya meningkatkan kemandirian belajarnya, sehingga dapat menumbuhkan motivasi belajar dan kreativitas, sehingga meningkatkan prestasi belajarannya dalam memenuhi kebutuhan untuk meningkatkan kemandirian belajar peserta didik. Pada gilirannya akan mendukung efektivitas implementasi pendidikan kesetaraan khususnya paket $\mathrm{C}$ di PKBM.

Model pembelajaran blended learning yang dikembangkan, pada implementasinya telah menunjukkan efektif dalam meningkatkan kemandirian belajar peserta didik program paket $\mathrm{C}$, dan bisa diterima sebagai alternatif pengembangan program pembelajaran yang lebih kontektual, efektif dan efisien sesuai dengan kondisi peserta didik. Dalam implementasinya, model pembelajaran yang 
dikembangkan menunjukkan efektif dalam meningkatkan kemandirian belajar peserta didik, sehingga dapat dijadikan altematif dalam membantu meningkatkan kemampuan peserta didik paket $\mathrm{C}$ di PKBM, agar penyelenggaraan program-program pendidikan luar sekolah berkembang ke arah yang lebih berkualitas, dan efektif. PKBM umumnya harus didukung oleh tutor dalam jumlah memadai, namun secara kualitas pembelajarannya masih lemah. Atas dasar hal tersebut, perlu diupayakan peningkatan kualitas pembelajaran secara lebih baik dan efektif.

Merujuk pada model pembelajaran blended learning sebagai upaya meningkatkan kemandirian belajar, maka peran tutor berdasarkan kajian teoretik maupun kajian empirik dalam kegiatan pembelajaran berfungsi: (1) menumbuhkan kesadaran peserta didi sebagai pelaku pembelajar dan pentingnya mereka untuk meningkatkan kemandirian dalam belajar; (2) membantu peserta didik sebagai pembelajar untuk bisa mengembangkan potensinya, sesuai bakat dan minatnya; (3) meningkatkan kesadaran peserta didik akan pentingnya kualitas diri secara efisien agar mencapai prestasi.

Fungsi lain mengenai Teknologi Informasi dan Komunikasi dalam konteks pembelajaran di kelas adalah sebagai alat atau sarana yang digunakan untuk melakukan perbaikan/ penyempurnaan kegiatan pembelajaran (Haddad, 2005 : 55). Sehingga para siswa menjadi lebih otonom dan kritis dalam menghadapi masalah, yang pada akhirnya bermuara pada peningkatan hasil belajar siswa (Karsenti, 2005 : 89). Teknologi Informasi dan Komunikasi dapat dan benar-benar membantu siswa mengembangkan semua jenis keterampilan, mulai dari tingkat yang sangat mendasar sampai dengan tingkat keterampilan berpikir kritis yang lebih tinggi (Mac Kinnon, 2005 : 111).

Berdasarkan fungsi tersebut menunjukkan tutor sebagai agen pembelajaran khususnya dalam penyelenggaraan program paket $\mathrm{C}$ di PKBM menuju pada pembelajaran yang lebih baik. Hal ini sesuai dengan salah satu prinsip pendidikan sepanjang hayat menurut Sudjana (2005: 217), bahwa pendidikan luar sekolah dikembangkan berdasarkan pada salah satu prinsip di antaranya, kegiatan belajar untuk memperoleh, memperbaharui, dan/atau meningkatkan pengetahuan, sikap dan keterampilan yang telah dimiliki oleh warga masyarakat sesuai dengan perubahan yang terus menerus sepanjang kehidupan.

Bagaimana tutor yang ada dapat memberikan pembelajaran yang berkualitas, sehingga PKBM tetap mampu memberi layanan pembelajaran yang optimal kepada peserta didik, termasuk pelayanan pendidikan kesetaraan paket $\mathrm{C}$. Altematifnya adalah membekali keterampilan mengajar dengan menggunakan media secara praktis dalam pembelajaran yang inovatif mereka melalui pembelajaran blended learning.

Hasil temuan penelitian ini menunjukkan bahwa rerata nilai kemandirian belajar peserta didik program paket $\mathrm{C}$ meningkat cukup baik. Hal ini ditandai dengan perolehan hasil belajar yang menunjukkan peningkatan positif dengan menggunakan media CD interaktif dan e-book dalam pembelajaran yang dilakukan tutor, serta respon peserta didik yang antusias terhadap penerapan model pembelajaran yang dikembangkan. Atas dasar hasil temuan dalam penelitian ini, maka model pembelajaran yang dikembangkan dikatakan 
efektif untuk meningkatkan kemandirian belajar peserta didik program paket $\mathrm{C}$ di PKBM.

\section{KESIMPULAN}

Berdasarkan pembahasan hasil penelitian di atas, maka dapat ditarik simpulan sebagai berikut: (1) Penggunaan media yang berbasis TIK dalam pembelajaran program paket $\mathrm{C}$ di PKBM pada umumnya belum optimal, karena terbatasnya sarana perangkat komputer yang dimilikinya. Sehingga pada waktu pembelajaran tatap muka secara klasikal. penggunaan media oleh tutor masih lemah. (2) Model konseptual pembelajaran blended learning merupakan sebuah model pembelajaran yang menggunakan media $C D$ interaktif dan e-book pada proses belajar mengajarnya, dan sekaligus merupakan sebuah alternatif pembelajaran untuk meningkatkan kemandirian belajar peserta didik program paket C pada PKBM. (3) Hasil implementasi model pembelajaran blended learning yang dikembangkan cukup efektif, di mana berpengaruh $48,2 \%$ terhadap peningkatan kemandirian belajar peserta didik program paket $\mathrm{C}$ pada PKBM.

\section{DAFTAR RUJUKAN}

Bersin, Josh. The Blended Learning Book Best Practices, Proven Methodologies and Lesson Learned. San Fransisco : John Weley, 2004.

Didarul Islam Manik and Charles A. Lubbers. Use of ICT and Traditional Agriculture Information Sources Bangladeshi Farmers, A Journal Of International Academy of Business Disciplines Volume 2 Number 4, Februari 2016, ISSN 2329-5163 (online). www.iabd.org. Diakses 29 Desember 2016
Gall, M.D. Gall J.P. \& Borg W.R. Educational Research An Introduction $7^{\text {th }}$. Edition. Boston: Pearson Education, Inc, 2003.

Havelock, R. G. Change The Agent's Guide. New Jersey, Educational Technologi Publications, Inc, 1991.

Haddad, Wadi D. Technology and Teacher Education: Making the Connection. http://www.techknowlogia.org. Diakses tanggal 28 Desember 2005

Hopkins, David. A Theacher's to Guide Classroom Research. Philladelphia: Open University Press, 1993.

Ibrahim Aly, Comparison of Students' Performance in a Managerial Accounting Course Taught in Blended Learning, Traditional Classroom, \& Online Setting, A Journal Of International Academy Of Business Disciplines Volume 2 Number 4, Februari 2016, ISSN 2329-5163 (online). www.iabd.org. Diakses 29 Desember 2016

Iskandar. Metodologi Penelitian Pendidikan dan Sosial. Jakarta: GP Press, 2009.

Isa, Yumanto. Pengembangan Model Blended Learning Mata Kuliah Perencanaan Teknologi Pembelajaran, Teknologi Informasi dan Komunikasi. Jurnal Teknologi Pendidikan Vol. 17 Nomor: 2. Agustus 2015, hal. 73-83, 2015.

Kamil, M. Teori Andragogi, dalam Ilmu dan Aplikasi Pendidikan. Bandung. Pedagogiana Press, 2007.

Karsenti, Thierry. From Blackboard to Mouse Pad: A Case Study of the Effectiveness of ELearning and Technology in Teacher EducationPrograms. http://www.Techknow logia.org. Diakses 19 April 2005

Lord, G. \& Lomicka L. Blended Learning in Teacher Education. An Investigation of Clasroom Community Across Media. Comtemporary Issues in Technology and Teacher Education, One way to Make It Effective. http://www.techknowlogia.org. Diakses 9 September 2005 
Mac Kinnon, Soledad. (2005). Technology Integration in the Classroom: Is There Only One way to Make It Effective (http://www.techknowlogia.org) Diakses 19 Juni 2005

Rosemarie Garner and Elizabeth Rouse, Social presence - connecting pre-service teachers as learners using a blended learning model, Directory of Open Access Journals (DOAJ), Student Success ISSN: 2205-0795 Volume 7, Issue 1, pp. 25-36 March 2016. https://studentsuccessjournal.org/article/view/ 299/307. Diakses 23 Desember 2016

Sudjana D. Strategi Pembelajaran dalam Pendidikan Luar Sekolah, Bandung: Nusantara Press, 2005.

Sugiyono, Metode Penelitian Kuantitatif, Kualitatif dan $R \& D$, Bandung, Alfabeta, 2007.

Sukardi. Metodologi Penelitian Pendidikan. Yogyakarta: Bumi Aksara, 2003.
Suryadi, A. Peningkatan layanan berbagai program pendidikan nonformal. Jakarta: Depdiknas, 2006.

Thorn, Kaye. Blended Learning. How to Integrate Online and Tradicional Learning, London : Kogen Page, 2003.

Wedemeyer, C.A. Criteria for Constructing a Distance Education System. Canadian J. Univ. Continuing Ed. VI ,Desember 1979. Halaman 9-17.

Won Sun Chen1 \& Adrian Yong Tat Yao. An Empirical Evaluation of Critical Factors Influencing Learner Satisfaction in Blended Learning: A Pilot Study. Universal Journal of Educational Research 4(7): 1667-1671, 2016. http:// www.hrpub.org DOI: 10.13189/ujer.2016.040719. Diakses 23 Desember 2016. 